\title{
Entrevista a Mark Blyth
}

\author{
26 de enero 2021
}

Revista Derechos en Acción ISSN 2525-1678/ e-ISSN 2525-1686

Año 6/No 18, Verano 2020-2021 (21 diciembre a 20 marzo), 863-867

DOI: https://doi.org/10.24215/25251678e501

Mark Blyth es profesor de Economía Internacional William R. Rhodes '57, en el Instituto Watson de Asuntos Internacionales y Públicos, de la Universidad de Brown (EEUU). Se doctoró en Ciencias Políticas en la Universidad de Columbia en 1999. Después se incorporó

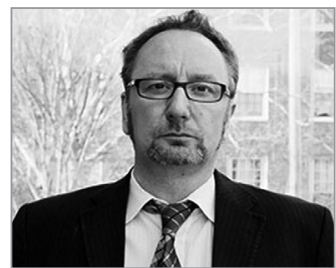
a la Universidad Johns Hopkins antes de tras-

ladarse a la Universidad de Brown en 2009. Su investigación se centra en las causas de la estabilidad y el cambio en la economía y en por qué la gente sigue creyendo en ideas económicas estúpidas a pesar de los cubos de pruebas en contra. El poder de las ideas económicas es un tema común en el trabajo de Blyth, como se ve en su reciente y premiado libro, Austeridad: Historia de una idea peligrosa (2015); The Future of the Euro (Nueva York: Oxford University Press 2015), y en su más reciente libro Angrynomics (Nueva York: Columbia University Press 2020).

\section{-Usted publicó un libro llamado Austeridad: Historia de una idea peligrosa. ¿Por qué la austeridad es peligrosa? ¿Quién gana y quién pierde con la austeridad?}

- La austeridad es una idea peligrosa porque es inmune a la refutación empírica. A nivel lógico, ya no importa cuántas veces se insista en esto:

a) el Estado no es un hogar; 
b) la capacidad para cobrar impuestos y emitir deuda a lo largo de generaciones es importante;

c) el gasto público no desplaza el privado si nadie más está gastando;

d) que no existe tal cosa como una contracción "expansiva";

e) no existen las "hadas de la confianza".

Los políticos seguirán diciendo que existen, y los economistas que los apoyan están básicamente participando de un tipo de política asociada a una clase social. La austeridad protege el valor de los activos de quienes los tienen, y dicha protección se paga recortando los gastos destinados a aquellos que no tienen activos. En términos de austeridad financiera, se trata de una "opción de venta de clase específica". La austeridad pone a salvo los activos de los ricos con los ingresos de los pobres. Es realmente así de simple.

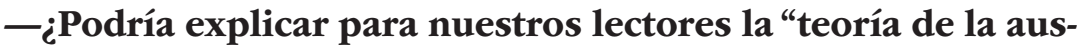 teridad expansiva" y cuáles son sus perspectivas al respecto?}

-Esta teoría estuvo muy en boga y decía que se podía tener "la chancha y los veinte". A partir de la experiencia de algunas pequeñas economías abiertas que recortaron sus gastos, y luego tuvieron un crecimiento que les permitió salir de la recesión en la que se encontraban - Dinamarca, Australia, Suecia o Irlanda-. Esta literatura les proponía a los políticos que era posible recortar gastos y hacer despegar la economía sin pagar el costo en las elecciones. Lo que estos estudios no decían era que el ajuste (si es que de hecho lo hubo) no guardaba ninguna relación con el despegue económico. Este había sido posible porque se trataba de pequeñas economías con grandes exportaciones, con lo cual el crecimiento de la economía de los países con los que comerciaban, mucho más grandes que ellos, estimuló las exportaciones y los ayudó a recuperarse. Los recortes nada tuvieron que ver con la recuperación. En algunos casos, como los de Suecia y Australia, los estudios llegaron incluso a malinterpretar lo que de hecho había sucedido en términos de políticas 
públicas. Australia no tuvo austeridad alguna y Suecia, por ejemplo, sufrió el colapso de su burbuja inmobiliaria. La Comisión Europea tomó estas ideas en 2010 y disparó una cruzada por la austeridad que aplastó el crecimiento por diez años y puso en jaque el sistema partidario de España, Italia y Francia. Al fin y al cabo, sí había que pagar un costo electoral.

\section{-Académicos y expertos hablan del peso desproporcio- nado que tienen las finanzas en la economía real. ¿Cómo cree que ha evolucionado esta hipertrofia desde la última crisis mundial? ¿Cómo impacta en la vida cotidiana de las personas y en las democracias?}

-Intento no utilizar expresiones como "hipertrofia financiera", pero la forma más simple de abordar esto es preguntándose si es posible que exista algo así como un exceso de finanzas. La respuesta es "sí", y en efecto esto sucede, especialmente, en el mundo angloamericano. Si bien el virus de la COVID vino a desafiar este modelo, a la hora de luchar contra las recesiones durante los últimos 30 años, los Estados prefirieron apoyarse en políticas monetarias por temor a aplicar políticas fiscales. El problema es que a medida que pasa el tiempo, se necesita cada vez más y más dinero para hacerlas funcionar. Y cuando ya no se tiene la capacidad de seguir bajando las tasas de interés, o para hacer que las personas sigan pidiendo préstamos porque ya tienen sus contabilidades en rojo, entonces las políticas monetarias pierden efectividad. Pero la deuda permanece y eso es fuente de fragilidad financiera para el período siguiente. Es por esto que me preocupa la inmensa acumulación de deuda privada, no pública. En el mundo hay 18 billones de dólares en deuda pública que tienen una rentabilidad negativa. Esto significa que los inversores les pagan a los Estados para que les presten dinero a tasa negativa. Ese no es el problema. Sino que los trabajadores y consumidores están pagando un $20 \%$ a las tarjetas de crédito y un $6 \%$ en créditos estudiantiles mientras que sus salarios se estancan. Esto es insostenible y, sin embargo, lo mantenemos crisis tras crisis. 
- La reacción inicial de la mayoría de los Estados ante la pandemia fue aparentemente la implementación de políticas que estimularan la economía. Ahora bien, ¿no nota acaso que los gobiernos y las IFI están hoy gradualmente desplazando su discurso y sus políticas hacia la austeridad? ¿Acaso no aprendieron nada de los últimos diez años de austeridad? ¿Existe alguna agenda racional y oculta que nos ayude a comprender por qué las IFI insisten nuevamente con la austeridad?

- La COVID ha hecho que los Estados cambiaran irrevocablemente la forma en la que hacen las cosas, con un repliegue fuerte en lo fiscal. Si el plan de recuperación de Biden es aprobado por el Senado estadounidense, entonces el gasto global de Estados Unidos desde el 2020 habrá sido mayor a todo el New Deal. Del mismo modo, la Comisión Europea anuló el paquete de medidas para el déficit y la deuda; y sería absurdo pretender aplicarlas en un mundo en el que, pasada la COVID, todos tendrán un $10 \%$ más de déficit. El año pasado, el execonomista jefe del FMI, Olivier Blanchard dijo que nos olvidáramos de posibles reducciones de deuda dado que los costos de reducirla son menores a los costos de vivir con ella. Italia representa una advertencia. Italia tiene un desempleo de dos dígitos desde los años de la austeridad y no tuvo crecimiento en 20 años. Está bajo la custodia del Banco Central Europeo. Los dos partidos políticos más importantes de Italia son fascistas blandos (Lega) o duros (Fratelli). Una ronda más de austeridad y llegarán al poder. Y creo que las IFI lo saben.

- ¿Qué responsabilidad tienen las IFI, particularmente el FMI, en la persistencia de ideas (y políticas) como la de la austeridad? ¿Qué conclusiones sacan los estudios técnicos y analíticos del FMI sobre los resultados de la aplicación de la austeridad? ¿El organismo considera estos estudios internos a la hora de tomar decisiones en términos de políticas?

- Históricamente tuvo mucha responsabilidad. Pero últimamente, no tanta. La actual directora del FMI dijo recientemente que la supervivencia triunfa sobre la rectitud fiscal y, ya en 2013, 
el departamento de investigaciones del FMI empezó a desandar los argumentos a favor de la austeridad. Para 2017, la ortodoxia había cambiado. El FMI ya se sentía sumamente incómodo continuando con la política de modificar los plazos de maduración de la deuda de Grecia en lugar de condonársela. Hubo cierto aprendizaje. Pero, ¿acaso importa a nivel operativo? ¿Cambia algo para los países de África subsahariana o América Latina que suelen estar endeudados con el FMI? En este punto, la evidencia es menos clara, pues se siguen aplicando las mismas condiciones y políticas de "privatización/liberalización" de antes. Es decir que sí, lo técnico y analítico importa, pero su repercusión en las políticas no está garantizada.

\section{- La pandemia exacerbó inequidades preexistentes y no exis- ten signos claros respecto de qué forma tomará la recupe- ración. ¿Cree que esto traerá una nueva ola de descontento mundial? ¿Cuál cree que será el uso político de este descon- tento en cuestiones económicas?}

-No cabe dudas de que la COVID profundizó las inequidades existentes. Aprendimos que los trabajadores esenciales son aquellos con salarios más bajos, y pareciera ser que para los gobiernos es más sencillo rescatar sus mercados de valores que proteger sus mercados de trabajo. Por otro lado, el alcance de esa protección, incluso en el Reino Unido, fue notorio. Así y todo, aunque el consumo se haya mantenido, los negocios están quebrando y puede que muchos nunca vuelvan a abrir. La recuperación estará determinada por los ahorros de aquellos menos afectados, que son aquellos con los salarios más altos. Este "gasto de lo acumulado" no va a "derramar" sobre los más afectados. Y las cuarentenas interminables van mermando la confianza pública y hacen a las poblaciones vulnerables a teorías conspirativas y otras manipulaciones. Estamos ante una carrera de tres pistas entre las vacunas, las mutaciones del virus y la capacidad de los gobiernos. Esta última se ha visto afectada a tal punto por los pasados periodos de austeridad que la recuperación será más difícil de lo que debería. 